\title{
The Effect of Using Pattern Guide Strategy on the Students' Reading Comprehension in Narrative Text
}

\author{
Syahreza Andika Gunawan \\ Balai Bahasa, Universitas Lancang Kuning, Pekanbaru. Indonesia \\ syahreza.andikag@gmail.com
}

\author{
Received : 2020-06-30 \\ Revised :2020-06-30 \\ Accepted : 2020-07-20
}

ARTICLE HISTORY

\section{KEYWORDS}

Pattern Guide Strategy Reading Comprehension Narrative Text

MTs Imam Ibnu Katsir

\begin{abstract}
The students in the eighth grade of MTs Imam Ibnu Katsir Pekanbaru had some phenomena in reading. First, the students got difficult in understanding the social function. The second, the students got difficult in understanding the grammar in narrative text. Concerning the syllabus of MTs Imam Ibnu Katsir Pekanbaru, the students' comprehension of social function, generic structure, and language features in narrative writing. This research aims to identify the effect of pattern guide strategy on the students' reading comprehension in narrative text. This research was conducted at the eighth-grade students of MTs Imam Ibnu Katsir Pekanbaru in January 2018. The research design used quasiexperimental research. The samples of this research were the students of class VIIIa consisting of 25 students and class VIIIb composed of 22 students. The data were collected by pre-test and post-test. Then, it was analyzed statistically by using SPSS verse 16.0. Then, the data were calculated by using N-Gain between pre-test and post-test in the experimental class. After conducting this research, the result of this research was that the post-test score of the experimental class was getting higher than the pre-test score. It can be seen from the average post-test score of the experimental class was 71.40, which improved from the pre-test score 56.80. The average post-test on the control class was 66.36 was lower than the experimental class. In conclusion, it can be stated that the students who are taught using pattern guide strategy achieve better than those who are not taught using pattern guide strategy.
\end{abstract}

\section{Introduction}

Derived from the School-Based Curriculum, reading comprehension in MTs Imam Ibnu Katsir Pekanbaru, especially for the eighth-grade students, there are several texts for the junior high school that should be taught by the teacher, they were descriptive text, narrative text, recount text, etc.

In this research, the researcher focused on the narrative text. The narrative text is kind of the text that retells the story in past tenses such us legend, fable, fairy tale, myths, folktale, etc. Here, the students should understand the social function, the structure of the text, and the linguistic elements of the narrative text. Besides, the students must grasp meaning simple narrative text in the form of oral and written form.

The narrative text consists of three parts; there are orientation, complication, and resolution. First, orientation: it sets the scene and introduces the participants and characters. Second, complexity is a series of complications or crisis points that arise in the story. Third, resolution: the crisis is resolved for better or for worse.
Based on the researcher's observation, during practice teaching at MTs Imam Ibnu Katsirn Pekanbaru, there were some phenomena in their reading comprehension. First, the students got difficult in understanding the social function. The second, the students got difficult in understanding the grammar in narrative text.

Based on the phenomena above, the researcher needs to try out the strategy to determine the effect on the students' understanding in reading narrative texts, namely, pattern guide strategy. A pattern guide is a strategy for teaching reading. Pattern guide is crucial for readers to use and identify text patterns while reading to comprehend text thoroughly. Text patterns offer the readers cues about how the information is organized. Incorporating a pattern guide is an excellent way for the teacher to assist students to recognize patterns and relationships in texts of any format. Wood $(2008: 137)$ states that understanding the organizational pattern facilitates learning within and across categories.

In learning theories further explain how learning takes places but not to identify particular strategies and practices that achieve the objectives outcomes of 
learning (Armayanti, 2018). Thus in language teaching particularly in reading activities, there are differ strategies and method to gain the objectives (Marpaung, Yanti \& Marzuki, 2019). Teaching reading by pattern guide strategy can give many advantages. Generally, it helps the teacher measure the students' reading comprehension and helps students become responsive to the various ways of textbook selection that can be organized (e.g., cause and effect, compare and contrast, sequence, enumeration). This type of strategy guide is developed to coordinate with the predominant pattern of a given text by Abid (2014:4). So, the researcher hopes the students can comprehend the narrative text with a pattern guide strategy, and not caused students do not concern in the conventional method in a learning activity (Putri et al., 2020)

According to Presetyo and Abbas (2017:103), reading is a process to get meaning from words, phrases, clauses, sentences, and texts. Reading is one of the crucial skills that students must master in learning English after listening, speaking, and writing.

Indonesia's education system is well aware of the importance of English (Rahman, 2018). As it is known that English is a foreign language that is rarely or not even used in day to day communication, particularly in countries that do not consider English as their official language (Nursafira, 2020). For teachers and learners, it is a challenge that always exist in teaching foreign language including teaching reading.

The result of the reading process is comprehension. It means that the reader understands, gets the information needed, and can retell to others. According to Mikulecky and Jeffries (2007:74), comprehending what you read is more than just recognizing and understanding words. It means that comprehension is making sense of what readers read and connecting the ideas in the text to what the reader already knows and remember what the reader has read. In other words, comprehending means thinking while you read.

Several types of text are learned in Junior High School, such as descriptive text, recount text, narrative text, etc. From some of the text, the researcher focused on the narrative text. This text is one of the text types learned by students at every education level, starting from high schools until university. According to Syafi'i (2007:53) at al narrative tells a story to make a point or explain an idea or event. The narrative is the kind of text that has purposes of entertaining and engaging the reader in an imaginative experience.

Furthermore, narrative text is organized by using story grammar. Story grammar is the knowledge of how stories are assembled with the beginning of the story containing the setting, the characters, and the characters' problem(s). A writer usually starts a story by introducing characters and challenges that they face. The middle of the narrative is organized around a plot. The plot includes a series of episodes written by the writer to hold the reader's attention and build excitement as the story progresses.

The narrative text has five standard components. Setting: A story can be set in the present, past, or future. Some stories are set in faraway lands or imaginary places, others set in familiar places. Authors may tell the reader the exact time or place of the story, but often these must be inferred by the reader. Characters: People or animals in the stories. Plot: The plot of the story is the sequence of events. The plot of the story takes the reader through events built to a climax or turning point in the story. The author then brings the story to a resolution. At times, an author may allow the reader to draw his conclusion about resolution. Theme: The theme is the central idea of the story. A theme can be directly stated or through the use of story elements. Vocabulary: The author uses vocabulary to enhance the reader's understanding of characters and events in the story. The author's choice of vocabulary produces the mood and tone of the story. Therefore, this study would like to set a selected strategy widely known as pattern strategy.

The quality of language learning is affected by the techniques used by learners (Rustam, Hamra \& Weda, 2016) and as a facilitator in learning, teachers and educators should be creative in creating learning strategies. In order to achieve the required learning objectives, a special treatment should be provided to help students improve their learning outcomes (Aswad et al., 2019). Pattern Guide strategy is a reading comprehension/ critical thinking activity for building knowledge in a reading lesson. Pattern guide strategy is a type of strategy guide. Wood (2008:4) stated that the strategy guide is also known as a reading guide are developing a graphic and questioning guide used to help students organize information as a means to comprehend what they are reading. It means that Students can arrange information into categories visually and succinctly that support their learning and studying.

Herber in Judy's book (2009:119) Pattern guides is most useful in helping students recognize a governing structure such as for cause and effect or comparison and contrast. To construct them, the teacher locates the pattern, chooses the major ideas to be stressed, and designs the pattern-oriented guide. It means that the teacher helps the students to understand the text by giving the pattern to the students.

Pattern guides can help readers recognize causal relationships as well as patterns of organization. It should be chosen or created by the teacher to match the text to help students know the relationship 
between main ideas and details and to facilitate notetaking while reading.

Teaching reading by using a pattern guide strategy can give many advantages. Generally, it helps students' become responsive to various textbooks. While individually, it is to help students recognize the relationship between main ideas and details as well as to facilitate note-taking while reading. On the other hand, pattern guide is useful in teaching reading comprehension.

To make it more transparent, here are the procedures of a pattern guide strategy by Wood (2008:137-138):

a) Before implementing the pattern guide, examine the text selection to determine the most common pattern. Keep in mind that patterns of text can vary throughout a book and that students are frequently unable to determine these patterns without sufficient teacher guidance.

b) Advise students on the pattern of the text; explain to students that their content area book contains various text patterns and that recognizing and using them can further their understanding of the material.

c) Model and guide students when introducing a text format or if they are having difficulty. In whole or small groups, discuss the text pattern under study using everyday examples before asking students to transfer their knowledge to their reading assignment. For example, if you are talking about the compare and contrast pattern, you might want to draw students' attention to words that signal this pattern. Next, model how these signal words are used in everyday speaking and reading to indicate that items, events, or people are being compared or contrasted. Consider the following example: "deserts may look desolate, but they are home to many species."

d) Assist students, and be sure that whole-class and small-group discussions are used frequently throughout the lesson to solidify understanding further and to correct possible misconceptions.

\section{Method}

This study was experimental research. According to Creswell (2005:282), the experiment tests an idea (or practice or procedure) to determine whether it influences an outcome or dependent variable.

Although all experiments have common characteristics, the most current research, the researcher was going to find in educational research was Quasi-experiment. In this type of experimental research, the researcher chooses Quasi-experimental (pre-test, post-test) in between-group research. According to Creswell (2005:295), between the group, research was the most frequently used designs in education are those where the researcher compares two or more groups.

Participant of this research was divided into two classes, namely one experimental class and one as control class. This study determined of control and experimental class based on the score MID Semester. In the experimental class, the researcher taught pattern guide strategy, and in the control class, the researcher taught the usual technique. The research has two variables, the implementation of the pattern guide strategy as the independent variable and the reading narrative text as the dependent variable.

\section{Findings and Discussion}

\subsection{The Result of the Research}

$$
\text { 3.1.1 Pre-Test }
$$

In the experimental research, the pre-test score is done by students who needed to be taken into account as the data. The students did the pre-test before the researcher gave treatment to the experimental group. The purpose of administering the pre-test was to find out the students' abilities before the treatment begins. As the researcher explained in the previous chapter, the test was reading test in a narrative text that should be done by students in the experimental group and control group, and the result of the pre-test can be seen in table 3.1 .

Table 3.1 Descriptive Statistics of Pre-test Score

\begin{tabular}{|c|c|c|c|c|c|}
\hline Value & Class & $\begin{array}{c}\text { Test } \\
\text { Ideal } \\
\text { Score }\end{array}$ & $\begin{array}{c}\text { Mastery } \\
\text { Min } \\
\text { score }\end{array}$ & $\begin{array}{c}\text { Concept } \\
\text { Max } \\
\text { score } \\
\end{array}$ & Average \\
\hline \multirow[t]{2}{*}{ Pre-test } & Experiment & 100 & $\begin{array}{l}3 \\
\mathbf{0}\end{array}$ & $\begin{array}{l}8 \\
0\end{array}$ & 56.80 \\
\hline & Control & 100 & $\begin{array}{l}3 \\
5\end{array}$ & $\begin{array}{l}7 \\
5\end{array}$ & $\mathbf{5 7 . 5 0}$ \\
\hline
\end{tabular}

Concerning table 3.1 above, it shows the minimum score on the experimental test class was 30, and control class 35. The maximum score on the experimental class was 80 , and the control class was 75. It concluded that the experimental class had 
knowledge that was lower than the control class that was having 57.50 as the average score. The pre-test of the pre-test experimental and control class can be seen in the following bar diagram below.

Based on the bar diagram above shows that the average experimental lower than the control class. The mean diagram can be seen experimental class achieved average 56.80 and control class achieved 57.50. After got the data comparison of pre-test experimental and control class, the researcher continued to calculate the normality test, homogeneity test, and continuity test of pre-test data by using parametric statistics, namely t-test or U-Mann Whitney test. The t-test can be used if the data normal and homogenous. At the same time, data is not reasonable or homogeneous. Then the data is calculated using non-parametric, namely U-Mann Whitney.

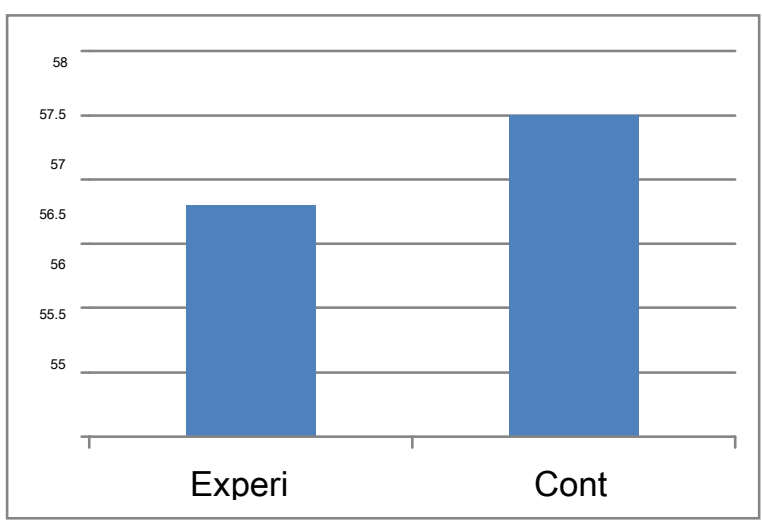

The normality test was done to see the data distribution was normal or not. It was the requirement for establishing the next step in parametric or nonparametric. Here the researcher used KolmogorovSmirnov (KS-21) as a formula to get the result or Normality test of pre-test of both classes can be seen in the following table.

Table 3.2 Normality Test of Pre-test

\begin{tabular}{ccccc}
\hline Class & $\begin{array}{c}\text { Asymp.Sig } \\
\text { (2-tailed }\end{array}$ & $\begin{array}{c}\text { a (significant } \\
\text { level) }\end{array}$ & Hypothesis & Distribution \\
\hline Experiment & 0.800 & 0.05 & Accept Ho & Normal \\
Control & 0.852 & 0.05 & Accept Ho & Normal \\
\hline
\end{tabular}

The next calculation of the pre-test of both

Table 3.2 above shows the normality test done of pre-test on experiment and control class in the distribution of data was normal. Experiment class in Asymp.Sig. (2-tailed) Was 0.800 with a significant level was 0.05 if the data value of was normal Asymp.Sig. (2- tailed) was $0.396>0.05$. It means that the distribution of data was normal, and the control class value of Asymp.Sig. (2-tailed) $0.852>0.05$. It means that the data distribution also was normal. classes was the homogeneity test. It was done to determine the sample's homogeneity, so it was gotten by comparing the value of based on trimmed mean with the level 0.05. And analyzing the data, this homogeneity test was calculated by Levene Formula. Best on the result of pre-test, both experiment, and control class got a homogeneity test:

Table 3.3 Homogeneity Test of Pre-test

\begin{tabular}{ccccc}
\hline Data & $\begin{array}{c}\text { Trimmed } \\
\text { mean }\end{array}$ & $\begin{array}{c}\text { a (significant } \\
\text { level) }\end{array}$ & Hypothesis & Distribution \\
\hline Post-test & 0.455 & 0.05 & Accept Ho & Homogenous \\
\hline
\end{tabular}

Regarding table 3.3, the pre-test homogeneity gained the value of based on trimmed mean that 0.455 with significant level 0.05 . That was why said that the pre-test on experiment class was coming from homogenous variance when based on mean $0.437>$ 0.05 . It means that pre-test data both the classes were from the homogeneous variance.
The t-test was the next testing because the data distribution of the pre-test was normal and homogenous; the test that considered was Asyp.Sig. (2-tailed) That was compared with a significant level of 0.05 when the data value of Asymp.Sig. (2-tailed) $<0.05$ so that the data differ significantly, but if the data value of Asymp.Sig. (2-tailed) >0.05. 
Table 3.4 T-test Result of Pre-test

\begin{tabular}{ccccc}
\hline Data & $\begin{array}{r}\text { Asymp.Sig. } \\
(2 \text {-tailed })\end{array}$ & $\begin{array}{c}\text { a } \\
(\text { significant level })\end{array}$ & Hypothesis & Significance \\
\hline $\begin{array}{r}\text { Pre- } \\
\text { test }\end{array}$ & 0.000 & 0.05 & Reject Ho & $\begin{array}{c}\text { Differ } \\
\text { significantly }\end{array}$ \\
\hline
\end{tabular}

As table 3.4 above, the t-test of both classes, experimental and control class differed significantly. It occurred since the value of Asymp. Sih (2-tailed) was 0.00. It means that Asymp.Sig. (2-tailed) $0.00<$ significant level 0.05 . Here the researcher concluded that the students' ability experimental and control class did not differ significantly.

Table 3.5 Descriptive Statistics of Post-Test Score

\begin{tabular}{|c|c|c|c|c|c|}
\hline \multirow[b]{2}{*}{ Value } & \multirow[b]{2}{*}{ Class } & Test & Mastery & Concept & \multirow[b]{2}{*}{ Average } \\
\hline & & $\begin{array}{l}\text { Ideal } \\
\text { score }\end{array}$ & $\begin{array}{c}\text { Minimum } \\
\text { score }\end{array}$ & $\begin{array}{c}\text { Maximum } \\
\text { score }\end{array}$ & \\
\hline \multirow{2}{*}{$\begin{array}{l}\text { Post- } \\
\text { test }\end{array}$} & Experiment & 100 & 40 & 90 & 71,40 \\
\hline & Control & 100 & 30 & 80 & 66,36 \\
\hline
\end{tabular}

Table 3.5 shows the maximum score, minimum score, and the average score of the post-test on experimental and control classes. The minimum score for the experimental class was 40, were the control class was 30 . The maximum score on the control class was 80 . It was lower than the score gained by experimental class 90 . Moreover, the average of posttest class on the experimental class was 71.40, and the control class for the proportion of post-test class on the control class was 66.36. Therefore, ability is the strength to do physical or mental things. It means that the student can write anything correctly and effectively (Ramadhan, 2019). The conclusion of the table above is it can be seen that for the post-test score, the experimental class was higher than the control class after giving some treatment.

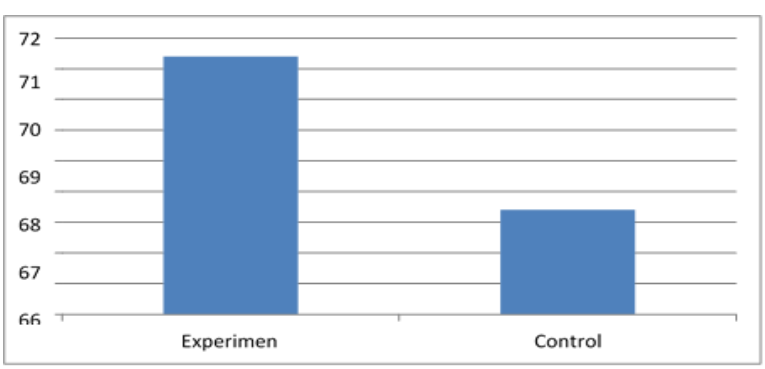

Diagram 3.2 Comparison Score Post-test of Experimental and control class

\subsubsection{Post-test}

Based on the data that had been collecting, experimental and control class were getting the posttest data in the following table:
The comparison of the post-test score of experimental and control class can be seen on the bar diagram below:

From the diagram above, the result of the average post-test of both class that was the average experimental class was seen higher 71.40, and the lower one got 66.36 on control class.

Of the data above, the next calculation was done normality test, homogeneity test, those tests were one of qualification for the continuing test. The data had normal and homogenous distribution; it was continued by using a t-test while data is not normal or not homogenous. The data is calculated using nonparametric, namely U-Mann Whitney.

The normality test was done to see the data distribute normally or not. It was the requirement forestablishing the next step in parametric or nonparametric. Here the researcher used KolmogorovSmirnov (KS-21) as the formula to get the result of the normality test of post-test of both classes can be seen in the following table: 
Table 3.6 Normality Test of Post-test

\begin{tabular}{ccccc}
\hline Class & $\begin{array}{c}\text { Asymp.Sig } \\
\text { (2-tailed) }\end{array}$ & $\begin{array}{c}\text { A (significant } \\
\text { level) }\end{array}$ & Hypothesis & Distribution \\
\hline Experiment & 0.249 & 0.05 & Accept Ho & Normal \\
Control & 0.021 & 0.05 & Reject Ho & Normal \\
\hline
\end{tabular}

Table 3.6 shows that the normality test of the post-test on experiment and control class had the normal distribution. Here experiment class had the column Asymp.Sig. (2-tailed) 0.249, it compared with a significant level

0.05 Asymp.Sig. (2-tailed) $>0.05$, it means that data was normal. While the control class got Asymp.Sig. (2-tailed) 0.021 with a significant level of 0.05 .

Table 3.7 Homogeneity Test of Post-test

\begin{tabular}{ccccc}
\hline Data & $\begin{array}{c}\text { Trimmed } \\
\text { mean }\end{array}$ & $\begin{array}{c}\text { a (significant } \\
\text { level) }\end{array}$ & Hypothesis & Distribution \\
\hline Post-test & 0.718 & 0.05 & Accept Ho & Homogenous \\
\hline
\end{tabular}

Of the table 3.7 the value of the trimmed mean was 0.718 , with level significant 0.05 . Based on trimmed mean was higher than level significant 0.05 . It could be said post-test data on experiment and control.

The class was homogenous variance because the trimmed mean $0.718>0.05$. It implies that homogenous.
Since data was normal and homogenous, so then the data could be calculated by using parametric. Here data calculated by T-test, Ttest was Asymp.Sig. (2-tailed) that compared with significant level 0.05 , when the data value of Asymp.Sig. (2-tailed) $<0.05$, so the data differ significantly, but if the data value Asymp.Sig. (2-tailed) $>0.05$. It does not vary significantly. The result of t-test on post-test can be seen in the table below:

Table 3.8 T-test Result of Post-test

\begin{tabular}{ccccc}
\hline Data & $\begin{array}{c}\text { Asymp.Sig. } \\
\text { (2-tailed) }\end{array}$ & $\begin{array}{c}\text { a (significant } \\
\text { level) }\end{array}$ & Hypothesis & significant \\
\hline Post-test & 0.00 & 0.05 & Reject Ho & $\begin{array}{c}\text { Differ } \\
\text { significantly }\end{array}$
\end{tabular}

The table provided above shows that the t-test of the post-test on the experiment and control class was differed considerably because of Asymp.Sig. (2tailed) $0.00<0.05$. It concluded that both classes differed significantly.

\subsubsection{N-Gain}

$\mathrm{N}$-Gain was used to know the effect size of the treatment that was given to the experimental class.
The calculation was performed based on the $\mathrm{N}$ Gain formula.

It was then compared with the criteria of achievement N-Gain. From the result of the N-Gain average value of the experimental class. It correlated with the criteria of success of $\mathrm{N}$-Gain value. The result of $\mathrm{N}$-Gain can be seen as follow: 
Table 3.9 N-Gain Score of Experimental Class

\begin{tabular}{cccccc}
\hline & & \multicolumn{3}{c}{ N-Gain } & \\
\cline { 3 - 5 } Test & N & Ideal & Minimum & Maximum & Average \\
& & score & score & score & \\
\hline Pre-test & 25 & 100 & 15 & 80 & 0.34 \\
Post-test & 22 & 100 & 40 & 90 & \\
\hline
\end{tabular}

Based on the table provided above, the average $\mathrm{N}$ Gain was 0.60 . It means that the critical strategy used in the experimental class was middle because the Average of $\mathrm{N}$-Gain was 0.34 . In the criteria of achievement, the $\mathrm{N}$-Gain score could be said middle if the score in $0.3<\mathrm{g}<0.7$. And the average of N-Gain was $0.3<0.34<0.7$. So it was middle. It can be concluded that there was a positive effect of the implementation of Pattern Guide Strategy in teaching reading the narrative text in the eighth grade of MTs Imam Ibnu Katsir Pekanbaru.

\section{Discussion}

This research was done in the eighth grade of Mts Imam Ibnu Katsir Pekanbaru. The sample of the study was VIIIa as the experiment class and VIII $b$ as the control class. Based on the result, it was proven that applying the Pattern Guide Strategy could increase the students reading comprehension in narrative text. There are some indicators in narrative text. The first indicator was to find specific information in the narrative text. As the teacher in learning activities, the researcher gives more explanation about particular information in narrative text and the students more active in the learning process.

The second indicator of reading comprehension in the narrative text is to find general understanding. For the students, general knowledge in narrative text scores from the post-test was higher than the pre-test. Because the teacher applies Pattern Guide Strategy in the learning process in the experimental class, the next indicator was to get social function in the narrative text to improve the students' reading comprehension because the students had understood the social function in the text. This indicator also scores from the post-test was higher than the pre-test.

The last $\mathrm{t}$ indicator of reading comprehension in the narrative text is found in the text's generic structure. The indicator of orientation could improve the teacher taught narrative text used Pattern Guide Strategy. The students had known and familiar with the story, especially the characters' place and time of the story. Next, the indicator of reading, namely complication, could improve because the students had been understood about the difficulty of the text and followed step. The next indicator was a resolution. The student's decision was enhanced because the teacher gave more explanation about the story and guided the students to apply the Pattern Guide Strategy. The students always practice reading the narrative text by using the Pattern Guide Strategy.

After giving treatment in the experimental class, there were 15 students got a higher score. It means that the Pattern Guide Strategy was made the students enjoy, interesting to answer the question during the learning process. But on the other hand, ten students could not answer all the questions well after the researcher gave a treatment. It meant, the mistake could come from the researcher as the teacher that explains the strategy, and the explanation was not apparent to the students. The last, even the Pattern Guide Strategy, was one effective strategy in teaching reading but could not improve all aspects of teaching reading.

As clarified previously, there was the positive effect of using Pattern Guide Strategy on reading comprehension of narrative text in the eighth grade of MTs Imam Ibnu Katsir Pekanbaru. This strategy helped the students read the narrative text correctly. Using this strategy could optimize the use of all potential of the students and keep the attention of students to remain focused on the learning process. In addition to the positive effects, there was also the weakness in using the Pattern Guide Strategy that was limited time in the classroom made some students not optimal to absorb learning.

This research also related to the research done by Abid (2014) conducted the research entitled "The Effect of Using Pattern Guide Strategy on Students' Reading Comprehension at State Senior High School 12 Pekanbaru" On this research he found in conclusion, there was a significant difference in the students' mean score in reading comprehension on analytical exposition text between pre-test and posttest after the treatment.

Sastiyanti (2009) researched "The Effect of Using Pattern Guide Strategy on students' reading comprehension in exposition text at the Second Year Students of SMA Negri 1 Bantul Yogyakarta". In her research, she found that the mean score of the experimental group, which was taught using a pattern guide, was categorized into a proper category while the mean score of the control group, which was 
taught by using conventional strategy, was categorized into enough category. So, the score of t0 was higher than the table. Therefore, h0 was rejected, and he was accepted. It means that there was a significant effect of using Read, Rate, and Reread Strategy on students' reading comprehension. In conclusion, for teaching reading narrative text, this is one way for the teacher to make the learning more attractive to their students.

\section{Conclusion}

Based on the purpose of this research to identify whether the students who received in-class instruction of Pattern Guide Strategy had different reading narrative text abilities than students who did not receive the direction of the strategy in the eighth grade of MTs Imam Ibnu Katsir Pekanbaru. It has been successfully showing the students who receive in-class instruction using Pattern Guide Strategy in reading narrative text achieve better than those who do not receive the instruction strategy.

There was a significant difference in the students' ability in reading narrative text between pre-test and post-test in the experimental class of using Pattern Guide Strategy at the eighth grade of MTs Imam Ibnu Katsir Pekanbaru, post-test score getting the higher score than pre-test score. It can be seen from the average post-test score of the experimental class was 71.40, and the pre-test score 39.60.

\section{Acknowledgment}

This research was partially supported by Balai bahasa Unilak. We thank our colleagues from PBIG FKIP Unilak who provided insight and expertise that greatly assisted the research, although they may not agree with all of the interpretations/conclusions of this paper.

\section{References}

Abid, M., (2014). The Effect Using Pattern Guide Strategy on Students' Reading Comprehension at State Senior High School 12 Pekanbaru. S1 Thesis, UIN Suska Riau.

Armayanti, R. (2019). Critical Discourse Analysis (CDA) on Qualitative Research: A Review. REiLA: Journal of Research and Innovation in Language, 1(1).

Aswad, M., Rahman, F., Said, I. M., Hamuddin, B., \& Nurchalis, N. F. (2019). A Software to Increase English Learning Outcomes: An Acceleration Model of English as the Second Language. The Asian EFL Journal. 26.(6.2), $157,169$.

Creswell, J. W. (2012). Educational research: planning. Conducting, and Evaluating.
Grabe, W., \& Stoller, F. L. (2001). Reading for academic purposes: Guidelines for the ESL/EFL teacher. Teaching English as a second or foreign language, 3, 187-203.

Harlan, A. F. (2016). The Implementation of Venn Diagram Strategy To Improve Reading Comprehension of Analytical Exposition Texts. Unpublished Thesis: Yogyakarta: Senata Dharma University..

Hornby, A. S. (2000). Wehmeier S, Ashby M. Oxford Advanced Learner's Dictionary of Current English.

Hudson, T. (2007). Teaching second language reading (p. 107). Oxford: Oxford University Press.

Klingner, J. K., Vaughn, S., \& Boardman, A. (2015). Teaching reading comprehension to students with learning difficulties, 2/E. Guilford Publications.

Knapp, P., \& Watkins, M. (2005). Genre, text, grammar: Technologies for teaching and assessing writing. UNSW Press.

Lubis, Z. (2010). Penggunaan Statistika Dalam Penelitian Sosial. Medan: Perdana.

Marpaung, A. P., Yanti, I., \& Marzuki, Y. (2019). Developing Students' Reading Comprehension Using STAD Strategy: A Classroom Action Research at SMA Negeri 7 Pekanbaru. REiLA: Journal of Research and Innovation in Language, 1(1).

Meltzer, D. E. (2002). The relationship between mathematics preparation and conceptual learning gains in physics: A possible "hidden variable" in diagnostic pretest scores. American journal of physics, 70(12), 1259-1268.

Mikulecky, B. S., \& Jeffries, L. (2007). Advanced reading power: Extensive reading, vocabulary building, comprehension skills, reading faster. Pearson Longman.

Ningsih, S. W., (2014). The effect of using authentic material toward the reading comprehension of the second year students of SMA N 5 Pekanbaru. S1 thesis, Islamic University of Riau.

Nunan, D. (2003). Practical english. Language Teaching. New York: Mc Graw Hill.

Nursafira, M. S. (2020). TED Talks in EFL Context: An Alternative Way for Teaching and Improving Student's Speaking Skills. ELSYA: Journal of English Language Studies, 2(2), 711. 
Presetyo, W., \& Abbas, M. (2017). The Use of Questioning the Author (Qta) Strategy in Improving Students' Ability in Reading Descriptive Text at the Seventh Grade Students of SMP Islam Plus Jannatul Firdaus Pekanbaru. ELT-Lectura, 4(2).

Putri, S. E., Hamuddin, B., Nursafira, M. S., \& Derin, T. (2020). Discourse Analysis in E-LearningBased Course Using Moodle Platform: An Experimental Design. REiLA: Journal of Research and Innovation in Language, 2(1).

Rafain, D., Amir, Z., \& Tiarina, Y. (2013). The Effect of Herringbone Technique On Students'reading Comprehension In Recount Text At Second Grade Of Smpn 2 Enam Lingkung Padang Pariaman. Journal of English Language Teaching, 2(1), 28-33.

Rahman, F. (2018). The Constraints of Foreign Learners in Reading English Literary Works: A Case Study at Hasanuddin University. Journal of Arts and Humanities, 7(2), 01-12.

Ramadhan, B. (2019). Writing Argumentative Essay: How Far They Can Go?. REiLA: Journal of Research and Innovation in Language, 1(2), 61-67.

Richardson, J. S., Morgan, R. F., \& Fleener, C. (2012). Reading to learn in the content areas. Cengage Learning.

Rustam, N. S., Hamra, A., \& Weda, S. (2016). The language learning strategies used by students of merchant marine studies polytechnics Makassar. ELT WORLDWIDE, 2(2), 77-94.

Sastiyanti., (2009). The Effect of Using Pattern Guide Strategy on students' reading comprehension in exposition text at the Second Year Students of SMA Negri 1 Bantul Yogyakarta. Unpublished Thesis. UGM. Yogyakarta

Snow, C. (2002). Reading for understanding: Toward an $R \& D$ program in reading comprehension. Rand Corporation.

Sugiyono., (2010). Statistika Untuk Penelitian. Bandung: CV. Alvabeta.

Syafi'i, M. (2007). The Effective Paragraph Developments: The Process of Writing for Classroom Settings. Pekanbaru: LBSI.

Veneranda, M. G., Marbun, R., \& Bunau, E. (2014). Teaching Reading Comprehension on Analytical Exposition Text By Using Multipass Strategy (Doctoral dissertation, Tanjungpura University).
Wood, C., \& Connelly, V. (Eds.) (2009). Contemporary perspectives on reading and spelling. Routledge.

Wood, K. D., Lapp, D., Flood, J., \& Taylor, D. B. (2007). Guiding readers through text: Strategy guides for new times. International Reading Assoc.

Yimwilai, S. (2009). Using narrative texts to teach reading. วารสาร มนุษยศาสตร์ ปริทรรศน์ (MANUTSAT PARITAT: Journal of Humanities), 29(1), 06-20 